\title{
Strategi Komunikasi Pemasaran UMKM di Bidang Makanan dan Minuman melalui Media Sosial Instagram di Tengah Pandemi Covid-19 di Indonesia
}

\author{
Fawwaz $^{1}$, Roswita Oktavianti ${ }^{2 *}$ \\ ${ }^{1}$ Fakultas Ilmu Komunikasi, Universitas Tarumanagara, Jakarta \\ Email: fawwaz.915180265@stu.untar.ac.id \\ ${ }^{2}$ Fakultas Ilmu Komunikasi, Universitas Tarumanagara, Jakarta* \\ Email: roswitao@fikom.untar.ac.id
}

Masuk tanggal : 15-12-2021 revisi tanggal : 06-01-2022, diterima untuk diterbitkan tanggal : 16-01-2022

\begin{abstract}
Early 2020 was the beginning of a tough year for small business in Indonesia, it is Sushi Komura who was the subject of research in this study. Sushi Komura is a food outlet that sells Japanese specialties, namely sushi. Marketing communications combined with marketing strategies and efforts to build positioning are carried out by many MSMEs so that sales continue to increase amid the Covid-19 conditions. To do this, of course, the company needs to identify the position of competitors who can determine the direction of the strategic position in building a positioning in the midst of business competition to attract consumer interest. Social media has an important role in building positioning activities for Sushi Komura SMEs. One of the things that need to be considered from using social media as a marketing medium and also building positioning is how the content can be of interest and liked by the audience, because if it is appropriate and appropriate, it can be an advantage for companies to attract buyers. The theory that helps this research is the theory of marketing communication strategy and positioning theory. The results of the findings of this study are that social media and also the application of cleanliness are the main keys for MSMEs to increase their selling power, besides that applying the right marketing strategy is also a determining factor for MSMEs to survive in the midst of the Covid-19 pandemic.
\end{abstract}

Keywords: communication strategy, marketing, MSME, positioning

\begin{abstract}
Abstrak
Awal tahun 2020 lalu menjadi awal tahun yang berat untuk pelaku usaha mikro, kecil dan menengah (UMKM) di Indonesia, salah satunya Sushi Komura yang menjadi subyek penelitian pada penelitian ini. Sushi Komura merupakan gerai makanan yang menjual makanan khas Jepang yakni sushi. Komunikasi pemasaran yang dipadukan dengan strategi pemasaran serta usaha membangun positioning dilakukan oleh banyak UMKM agar penjualan tetap meningkat ditengah kondisi Covid-19. Untuk menjalankan hal tersebut tentunya perusahaan perlu mengidentifikasi posisi pesaing yang dapat menentukan arah strategi dalam membangun positioning ditengah persaingan usaha untuk menarik minat konsumen. Media sosial memiliki peranan yang penting dalam kegiatan membangun positioning bagi UMKM Sushi Komura. Salah satu hal yang perlu diperhatikan dari penggunaan media sosial sebagai media pemasaran dan juga membangun positioning adalah bagaimana konten tersebut dapat diminati dan disukai oleh khalayak, karena apabila sudah sesuai dan tepat dapatlah menjadi keunggulan bagi perusahaan untuk menarik minat pembeli. Teori strategi komunikasi pemasaran merupakan teori yang dipilih untuk membantu penelitian ini. Hasil dari temuan penelitian ini bahwa media sosial dan juga penerapan kebersihan menjadi kunci utama bagi UMKM untuk meningkatkan daya jual, Terlepas dari hal itu, menerapkan berbagai strategi pemasaran juga dapat menjadi faktor penentu bagi UMKM untuk bertahan di tengah pandemi Covid-19.
\end{abstract}


Kata Kunci: pemasaran, positioning, strategi komunikasi, UMKM

\section{Pendahuluan}

Covid-19 menjadi bencana besar hingga berdampak pada pelaku usaha mikro, kecil dan menengah (UMKM) di Indonesia, termasuk Sushi Komura yang menjadi subyek penelitian pada skripsi ini. Secara ringkas dampak dapat diartikan sebagai pengaruh atau akibat, dalam setiap keputusan maupun keadaan yang diambil oleh seseorang yang memiliki pengaruh dalam suatu tempat (Tampi, 2016). Dalam hal ini dampak terbagi menjadi dua, dampak positif dan dampak negatif. Covid-19 ini tentunya mengakibatkan dampak negatif karena merugikan banyak pihak. Sedangkan menurut undang-undang nomor 20 Tahun 2008 tentang usaha mikro, kecil dan menengah (UMKM) memiliki arti usaha perdagangan yang dikelola oleh perorangan ataupun badan usaha dan sesuai dengan kriteria usaha dalam lingkup kecil atau juga mikro. Komunikasi pemasaran yang dipadukan dengan strategi pemasaran serta usaha membangun positioning dilakukan oleh banyak UMKM agar penjualan tetap meningkat ditengah keadaan Covid-19. Strategi ialah tindakan yang sifatnya incremental (senantiasa meningkat) dan secara terus menerus, dan juga dilakukan berdasarkan sudut pandang tentang apa yang diharapkan oleh pelanggan. Strategi selalu dimulai dari apa yang dapat kemungkinan terjadi dan bukan dari apa yang sudah dan sedang terjadi (Hamel dan Prahalad, 1995).

Dalam usaha menarik minat pelanggan, pelaku usaha juga menerapkan komunikasi pemasaran, yaitu usaha untuk menyampaikan pesan kepada publik atau konsumen guna mengetahui perbedaan produk kita dipasar lainnya, kegiatan ini merupakan rangkaian untuk mewujudkan suatu produk, jasa, ide, dengan menggunakan berbagai cara yaitu iklan, penjualan tatap muka, promosi penjualan dan masih banyak lainnya (Sutisna, 2006). Komunikasi pemasaran juga sebuah aktivitas yang bertujuan untuk menyampaikan informasi kepada khalayak, menimbulkan perasaan tertarik terhadap merek atau produk, serta mendapatkan rasa yakin kepada khalayak (Machfoedz, 2010).

Strategi komunikasi yang tepat memungkinkan tindakan komunikasi agar target-target khalayak sadar bahwa ia memerlukan suatu produk, jasa atau nilai dan ketika perhatian dari khalayak sudah terbangun. Maka selanjutnya adalah bagaimana komunikator membangun hubungan agar target khalayak menjadi loyal untuk membeli produk, jasa atau nilai itu (Bungin, 2015). Strategi komunikasi kiranya dapat mencakupi segala pengetahuan tentang bagaimana cara untuk berkomunikasi dengan khalayak sasaran mengenai bagaimana khalayak sasaran akan memahami manfaat dari berkomunikasi dengan salah satu pihak tersebut. Serta bagaimana khalayak sasaran dapat terjangkau lebih luas dan efektif (Effendy, 2003).

Rumusan masalah yang difokuskan dalam penelitian ini adalah bagaimana strategi komunikasi pemasaran UMKM di sektor makanan dan minuman dalam membangun positioning di tengah pandemi Covid-19 yang bertujuan untuk mengetahui bagaimana strategi komunikasi pemasaran UMKM sektor makanan dan minuman dalam membangun positioning di tengah pandemi Covid-19 tersebut dapat berjalan.

Dalam penelitian ini, penulis akan meneliti mengenai apa saja strategi pemasaran yang digunakan oleh Sushi Komura guna membangun positioning di tengah pandemi Covid-19. Strategi pemasaran dari sebuah perusahaan sangatlah berkaitan dan mempengaruhi bagaimana konsumen dapat menciptakan citra atau 
gambaran terhadap perusahaan tersebut. Sushi Komura yang hadir pada bulan juni tahun 2021 didirikan oleh Fitzal Paleva, pemuda berumur 21 tahun. Menurutnya, Sushi Komura berfokus pada penjualan makanan khas Jepang yaitu sushi. Sushi Komura bertempat di Jl.Pekiringan no.51 kota Cirebon, Jawa Barat.

Di kota Cirebon sendiri, Sushi Komura merupakan satu-satunya UMKM yang menjual produk makanan dan minuman khas Jepang. Seperti yang sudah dijelaskan di atas bahwa Sushi Komura hadir pada bulan juni tahun 2021 yang mana masih terjadinya pandemi Covid-19. Hadir ditengah bencana pandemi Covid-19 dan masih bertahan hingga saat ini penilitian ini ditulis, mendorong peneliti untuk meneliti bagaimana Sushi Komura menerapkan strategi pemasaran guna membangun positioning ditengah pandemi Covid-19.

\section{Metode Penelitian}

Penulis menggunakan pendekatan penelitian kualitatif, pendekatan yang memiliki tujuan untuk memaksimalkan penelitian dengan lebih mendalam tentang bagaimana strategi komunikasi pemasaran UMKM di bidang makanan \& minuman dalam membangun positioning di tengah pandemi Covid-19 di Indonesia. Penelitian kualitatif merupakan penelitian guna mendapatkan data deskriptif yang berupa katakata tertulis maupun secara lisan dari orang serta perilaku yang dapat diamati (Moleong, 2010). Moleong berpendapat bahwa penelitian kualitatif merupakan penelitian yang bertujuan agar peneliti dapat mengetahui tentang fenomena apa yang diketahui oleh subyek dalam penelitian, contohnya ialah persepsi, perilaku, motivasi, tindakan, secara holistic maupun secara deskriptif dalam bentuk kata dan juga bahasa maupun secara lisan.

Berdasarkan pendapat di atas maka dapat disimpulkan bahwa penelitian kualitatif merupakan penelitian yang menempatkan subjek penelitian sebagai kunci utama dalam penelitian, kemudian hasil dari pendapat subjek penelitian dapat diuraikan dalam bentuk kata tertulis data empiris yang diperoleh dalam penelitian ini.

Dalam melakukan pengumpulan data, peneliti akan melakukan metode pengumpulan data dengan cara observasi, dokumentasi serta studi kepustakaan, penulis juga melakukan wawancara kepada 2 (dua) narasumber, yaitu Fitzal Paleva, Victoria Tabitha. Analisis data, pada penelitian ini akan menggunakan cara menurut penjelasan pada penelitian Ade Novianti (2017), yaitu dengan melalui proses Reduksi data, display data (penyajian data), dan verifikasi data (kesimpulan data) (Novianti, 2017).

Dalam pengerjaannya juga penelitian ini menggunakan metode studi kasus. Dijelaskan oleh Creswell bahwa studi kasus bertujuan untuk mengeksplorasikan sistem-sistem yang keterkaitan dengan suatu kasus.

Dalam penelitian ini yang menjadi subjek ialah strategi pemasaran komunikasi UMKM Sushi Komura. Narasumber dalam penelitian ini terdiri atas 2 (dua) orang, yakni Fitzal Paleva dan Victoria Tabitha. Alasan dipilih ketiga orang tersebut sebagai narasumber karena mereka merupakan pendiri dan juga pencetus dari terbentuknya Sushi Komura dan juga berperan aktif dalam merancang strategi pemasaran komunikasi Sushi Komura itu sendiri.

Pengumpulan data yang akan dilakukan dalam penelitian ini berupa informasi yang memiliki keterkaitannya dengan masalah yang akan diteliti yakni bagaimana strategi pemasaran komunikasi Sushi Komura dalam membangun positioning di tengah pandemi Covid-19. 
Guna mendukung keabsahan data yang diperoleh dari penelitian ini, Peneliti menggunakan teknik triangulasi. Teknik ini merupakan teknik yang menjadikan dokumen, arsip, dan hasil observasi sebagai sumber data pendukung atas data yang sudah didapatkan sebelumnya (Moleong, 2010).

Pada penelitian ini penulis menggunakan Triangulasi Teori sehingga mendapatkan jawaban akhir yang valid serta akurat. Triangulasi teori merupakan usaha untuk memanfaatkan 2 (dua) teori atau lebih untuk diadu maupun dipadu. Maka dari itu, diperlukanlah rancangan riset, pengumpulan data, dan juga terakhir analisis data yang lengkap agar nanti nya hasil di dapatkanlah hasil akhir yang komprehensif (Novianti, 2017).

\section{Hasil Temuan dan Diskusi}

Sushi Komura merupakan sebuah usaha yang menjual produk berupa makanan khas Jepang yang berdiri pada bulan April Tahun 2021. Sushi Komura berada di Jl. Pekiringan, No.133, Kecamatan Pekalipan, Kota Cirebon 45133. Sushi merupakan makanan khas Jepang yang terdiri dari perpaduan antara nasi dan cuka beras yang dikemas bersama lauk berupa makanan laut, daging, sayuran mentah atau sudah matang.

Sushi Komura didirikan oleh seorang pemuda yang Bernama Fitzal Paleva (21), menurutnya Sushi Komura berdiri karena di Cirebon belum pernah ada makanan jalanan yang menjual makanan khas Jepang. Melihat peluang bisnis yang menjanjikan, Fitzal Paleva bersama Victoria Tabitha (21) yang ahli dalam bidang publikasi dan dokumentasi sepakat untuk membangun bisnis bersama yang akhirnya mereka namakan "Sushi Komura" yang bermakna Sushi Kok Murah karena memang mereka menjual produk sushi yang begitu murah dan jauh dari harga pasaran pada umumnya.

Dari hasil penelitian dengan metode wawancara, ditemukan bahwa dalam menjalankan strategi pemasarannya UMKM Sushi Komura menggunakan media sosial sebagai media utama untuk memasarkan produknya terutama melalui media sosial Instagram. Hal ini memungkinkan agar informasi yang disampaikan oleh Sushi Komura dapat diterima tepat sasaran sesuai dengan target sasaran khalayak Sushi Komura. Media sosial ialah suatu kumpulan grup aplikasi yang berbasiskan internet, pengguna dapat membuat atau bertukar informasi terkait suatu hal apapun dalam media sosial tersebut (Kaplan dan Haeanlin, 2010). Instagram dapat kita pahami sebagai suatu media yang dapat mengunggah dan dan mengunduh dalam waktu singkat.

Selain itu, ditemukan juga bahwa Sushi Komura menggunakan kekuatan word of mouth sebagai cara untuk memasarkan Sushi Komura, karena menurut penuturan Fitzal Paleva selaku pemilik word of mouth sangatlah berpengaruh dalam penjualannya. Word of mouth merupakan komunikasi secara pribadi atau interpersonal antara dua atau lebih masing masing yang bertujuan sebagai salesperson.

Tindakan word of mouth dapat diartikan sebagai usaha pemasaran yang memicu konsumen agar membicarakan, memasarkan, merekomendasikan serta menjual dari produk yang dijual kepada pelanggan lainnya (Sumardy,2007). Silverman menjelaskan bahwa word of mouth is communication about products and services between people that perceived to be the independencial of the company who providing those product or services.

Word of mouth dapat dijalankan dengan efektif apabila memiliki 5 (lima) aspek hal yang terdiri dari: 
a. produk serta layanan yang baik. Dalam hal ini perusahaan perlu memberikan kualitas serta layanan produk kepada opinion leader maupun khalayak sehingga mereka mendapatkan kepuasan tertentu.

b. rencana, perusahaan memerlukan rencana yang baik dan rinci dengan mempertimbangkan beberapa aspek guna berjalannya kegiatan world of mouth oleh khalayak.

c. pesan, dalam kegiatannya perusahaan perlu menjelaskan pesan yang bersih, teliti, dan juga konsisten kepada khalayak/pelanggan.

d. persiapan, perusahaan perlu mempersiapkan tenaga kerja penjualan yang mumpuni dan juga memiliki pengetahuan yang luas akan produk yang akan mereka jajalkan.

e. terakhir, perusahaan memerlukan sesoerang yang mau untuk beraksi menjalankan kegiatan word of mouth sebagaimana mestinya. (Barber and Wallace, 2009).

Terkait usaha membangun positioning ditemukan bahwa UMKM Sushi Komura berfokus membangun positioning dengan cara mengedepankan protokol kesehatan dan juga melalui media sosial karena dinilai saingan mereka tidak memiliki media sosial yang mumpuni sebagai mana Sushi Komura. Hal ini dapat dikaitkan dengan teori positioning yang dijelaskan oleh Kotler (2007) bahwa positioning merupakan suatu tindakan merancang tawaran serta membangun citra perusahaan hingga dapat menempati posisi yang khas dalam benak pelanggan yang menjadi target khalayak sasaran.

Pernyataan narasumber terkait hal ini dapat didukung berdasarkan hasil wawancara dengan narasumber sebagai berikut:

"Oke, tentunya kita menerapkan protokoler yang ada. Karna saat ini sedang pandemic agar makanan itu lebih higienis. Karena dengan higienis itu konsumen jadi merasa nyaman, oke jadi kita beli Sushi Komura itu karena protokoler yang ada dan tidak takut gitu. Jadi kita mengutamakan kebersihan gitu. Dan juga kita tentu nya itu tadi kita menyediakan sushi dengan harga yang murah dan kasih tau ke masyarakat kalau makan sushi itu ga harus di restoran gitu." (Wawancara dengan Fitzal Paleva, Pemilik UMKM Sushi Komura, 3 November 2021)

Sushi Komura hadir dan mengubah ekspetasi masyarakat umum terkhusus Kota Cirebon bahwa makan sushi tidak harus mahal dan tidak harus di resotran. Strategi inilah yang menurutnya menjadi cara utama Sushi Komura membedakan dengan brand sushi lainnya.

Dari observasi yang telah peneliti lakukan dengan melakukan perbandingan harga antara Sushi Komura dengan brand sushi lainnya di Kota Cirebon, Sushi Komura memang menjual dengan harga yang jauh lebih murah dari yang lainnya. Selain mengedepankan protokol kesehatan dengan mewajibkan seluruh staf menggunakan masker dan juga pelindung tangan serta mewajibkan seluruh pelanggan untuk menggunakan masker ketika sedang di tempat, menjajalkan sushi dengan harga yang murah juga terbukti menjadi pendorong bagi Sushi Komura untuk membangun positioning mereka.

Sushi Komura juga berusaha membedakan identitas dengan cara meningkatkan dan berfokus pada konten konten media sosial. Kaitannya dengan media sosial sebagaimana saingan Sushi Komura tidak memiliki media sosial yang mumpuni, dapat 
dikaitkan dengan teori positioning yang dijelaskan oleh Rhenald Kasali (2011) bahwa positioning ialah strategi untuk memasuki jendela otak konsumen, agar nantinya produk maupun jasa suatu produk memiliki arti khusus dalam artian keunggulannya.

Pernyataan narasumber terkait hal ini dapat didukung berdasarkan hasil wawancara sebagai berikut :

"Untuk membangun positioning tentu saja kita siapin konten untuk Instagram, nah untuk konten sendiri kita udah bener bener susun copywritingnya. Yang bikin kita itu beda saingan kita udah gaada yang bangun positioning dan brand awareness lewat Instagram. Jadi kaya menarik perhatian audience gitu untuk calon calon pembeli yang baru." (Wawancara dengan Victoria Tabita, Content Creator Sushi Komura, 3 November 2021)

Gambar 1. Instagram Sushi Komura

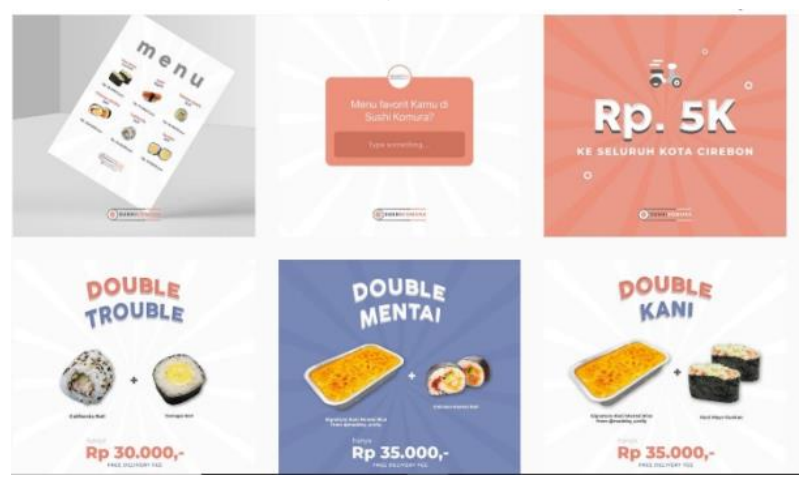

Sumber: Instagram @Sushikomura.crb

Peneliti menemukan hasil bahwa dengan digunakannya Instagram sebagai wadah bagi Sushi Komura memasarkan produknya sangatlah berpengaruh bagi mempengaruhi keputusan pelanggan untuk datang ke Sushi Komura. Karena mayoritas pelanggan yang datang ke Sushi Komura mengetahui keberadaan dan eksistensi Sushi Komura melalui Instagram. Pernyataan narasumber terkait hal ini pun dapat didukung dengan hasil wawancara sebagai berikut :

"Dampak yang paling berasa sih kita ga expect kalau bisa sampe menjangkau calon pembeli yang memang kita gapernah tau dan gakenal, mereka tiba tiba DM dan dateng ke kita. Terus kalau kita tanya tau kita darimana mereka jawab tau kita dari Instagram." (Wawancara dengan Victoria Tabita, Content Creator Sushi Komura, 3 November 2021).

\section{Simpulan}

Berdasarkan hasil penelitian yang telah dilakukan oleh peneliti mengenai strategi komunikasi pemasaran UMKM di bidang makanan dan minuman melalui media sosial Instagram di tengah pandemi covid-19 di Indonesia, dapat peneliti simpulkan bahwa dalam melakukan strategi komunikasi guna membangun positioning yang dilakukan UMKM Sushi Komura berlandaskan dengan teori word of mouth seperti yang sudah dijelaskan sebelumnya oleh peneliti. Strategi yang digunakan dinilai sudah tepat sasaran dengan target khalayak dari Sushi Komura, serta dapat dikatakan berhasil dalam menjalankan strategi pemasaran UMKM Sushi Komura.

Terkait usaha membangun positioning yang dilakukan UMKM Sushi Komura, dapat peneliti simpulkan bahwa yang mereka lakukan berlandaskan dengan teori 
positioning seperti yang telah dijelaskan oleh Rhenald Kasali. Dalam hal ini terkait menunjukkan perbedaan produk yang dilakukan dengan satu-satunya UMKM sushi yang mengedepankan sosial dan juga dengan menunjukkan kelebihan dari produk, yakni dengan menjadi UMKM yang menjaga protokol Kesehatan dengan ketat hingga dapat membangun kepercayaan masyarakat.

Strategi pemasaran yang dilakukan oleh UMKM Sushi Komura dan bidang makanan dan minuman lainnya, dalam membangun positioning ditengah pandemi covid-19 dinilai sudah sesusai dan tepat sesuai dengan keadaan dalam pengerjaanya, namun peneliti menyarankan untuk UMKM Sushi Komura agar senantiasa berinovasi dalam menjalankan strategi pemasaran dan juga membangun kepercayaan masyarakat, agar dapat lebih dikenal dan mengembangkan UMKM Sushi Komura agar dapat menjadi usaha dengan skala besar. Selain itu, disarankan perlu dibuat berbagai program program promosi guna menarik minat pelanggan lebih luas

\section{Ucapan Terima Kasih}

Penulis mengucapkan terima kasih kepada Fakultas Ilmu Komunikasi Universitas Tarumanagara dan narasumber atas dukungan dan bantuannya kepada penulis dalam menyelesaikan penelitian ini.

\section{Daftar Pustaka}

Barber, Peggy; Wallace, Linda. (2009). Building a Buzz \& Word of Mouth Marketing. USA: American Library Association.

Bungin, Burhan. 2015. Komunikasi Pariwisata (Tourism Communication): Pemasaran dan Brand Destinasi. Jakarta: PRENADAMEDIA GROUP.

George, Silverman, 2001, The Secrets of Word-of-mouth Marketing: How to Trigger Expontials Sales Through Runaway Word-ofmouth. New York: Amacom.

Hamel, G dan Prahalad, C, K, 2006. Rangkuti. Jakarta: Bina Rupa.

Kasali, Rhenald. 2011. Membidik Pasar Indonesia: Segmentasi, Targeting, dan Positioning. Jakarta: PT Gramedia Pustaka Utama.

Kotler, Philip dan Kevin Lane Keller, 2009. Manajemen Pemasaran, Edisi 12 jilid 1. Jakarta: PT. Indeks.

Kaplan, A, M., \& Haenlein, M. 2010. Users of the world, unite! The challenges and opportunities of social media. Business Horizons, Vol. 53 No. 1, pp. 59-68.

Moleong, Lexy J. 2006. Metodologi Penelitian Kualitatif. Bandung. PT. Remaja Rosdakarya.

Novianti, Ade. (2017). Pola Dan Jaringan Komunikasi Tentang Pengangkatan Anak Secara Adat Pepadun Di Kabupaten Lampung Tengah (Studi Pada Kelompok Adat Di Pekon Way Buyut Lampung Tengah). April 15, 2020.

Rulandari, Novianti. 2020. Strategi Komunikasi Pemasaran Usaha Mikro Kecil dan Menengah Pada Era New Normal. STIAMI. 